\title{
Russian Migration and Psychological Aspect
}

\section{Migración Rusa y Aspectos Psicológicos}

\author{
Galina V. Petruk* \\ Vladivostok State University of Economics and Service, Russia \\ ORCID: https://orcid.org/0000-0002-1025-3605 \\ Angelina G. Kim \\ Vladivostok State University of Economics and Service, Russia \\ ORCID: https://orcid.org/0000-0002-3152-3467
}

\section{Anastasia S. Vaschuk}

Institute of History, Archaeology and Ethnography of the Peoples of Far-East, Russia ORCID: https://orcid.org/0000-0002-8258-6310

\section{*Correspondence}

Email: pigenko_galina_8@mail.ru
Cite as:

Petruk, G. V., Kim, A. G., \& Vaschuk, A. S. (2020). Russian Migration and Psychological Aspect.Propósitos y Representaciones, $\quad 8(2), \quad$ e513. doi: http://dx.doi.org/10.20511/pyr2020.v8n2.513 


\section{Summary}

The problem of regional migration is treated in the article. The development of the Far Eastern territories is a priority now. The government has developed many large-scale projects aimed at supporting the remote region, but the problem of emigration of the economically active population has not settled since 1991. The problem of the outflow of promising young personnel from its territory is particularly acute. The purpose of this research is to study the reasons for the migration of young people from the Primorsky Region - one of the regions of the Far East. The main tasks were to obtain visions of migration moods and motivation of migration behavior of students. The study used a psychological verbal-communicative method - a survey in which a specially designed list of questions was used as a means to collect information from the respondent. The survey covered about 1,000 respondents between the ages of 15 and 30. The research has shown that the main reason for emigration of school graduates is the opportunity to progress, studying in prestigious domestic and foreign universities, working in the largest Russian and foreign companies, that not enough represented here. Excellent and good rated school graduates prefer to enter Moscow and St. Petersburg universities. This means that most prospective workers in the future want to leave the territory of the region. Analysis of the responses of the university graduates revealed the prevalence of negative expectations about their future and the future of the territories. The data indicated that the main reasons to leave the country and the Primorsky Region are low job prospects for university graduates, lack of self-realization possibilities, low wages and the instability of the region's political and socio-economic situation. In addition, the situation is exacerbated by the fact that respondents, for the most part, do not know about the projects that are being implemented in the region and do not see career prospects, which confirms the implementation of many strategic projects of the region only on paper. The lack of measures to prevent the emigration of young people will have a number of negative economic and social consequences, one of which is the reduction of competitevness of the territory. Creating favorable conditions for young people in the region, active public policy to attract young skilled professionals in Primorye is a prerequisite for the development of the region's intellectual capital and a guarantee of its dynamic socio-economic development.

Keywords: Migration; Migration Preferences; Student Migration; Regional Features.

\section{Resumen}

El problema de la migración regional se trata en el artículo. El desarrollo de los territorios del Lejano Oriente es una prioridad ahora. El gobierno ha desarrollado muchos proyectos a gran escala destinados a apoyar a la región remota, pero el problema de la emigración de la población económicamente activa no se ha resuelto desde 1991. El problema de la salida de jóvenes prometedores de su territorio es particularmente grave. El propósito de esta investigación es estudiar las razones de la migración de jóvenes de la región de Primorsky, una de las regiones del Lejano Oriente. Las tareas principales fueron obtener visiones de los estados de ánimo migratorios y la motivación del comportamiento migratorio de los estudiantes. El estudio utilizó un método psicológico verbal-comunicativo, una encuesta en la que se utilizó una lista especialmente diseñada de preguntas como un medio para recopilar información del encuestado. La encuesta abarcó a aproximadamente 1,000 encuestados entre las edades de 15 y 30. La investigación ha demostrado que la razón principal de la emigración de los graduados de la escuela es la oportunidad de progresar, estudiando en prestigiosas universidades nacionales y extranjeras, trabajando en las mayores universidades rusas y extranjeras. empresas, que no están suficientemente representadas aquí. Los graduados de escuelas excelentes y con buena calificación prefieren ingresar a las universidades de Moscú y San Petersburgo. Esto significa que la mayoría de los futuros trabajadores en el futuro desean abandonar el territorio de la región. El análisis de las respuestas de los graduados universitarios reveló la prevalencia de expectativas negativas sobre su futuro y el futuro de los territorios. Los datos indicaron que las principales 
razones para abandonar el país y la región de Primorsky son las bajas perspectivas laborales para los graduados universitarios, la falta de posibilidades de autorrealización, los bajos salarios y la inestabilidad de la situación política y socioeconómica de la región. Además, la situación se ve exacerbada por el hecho de que los encuestados, en su mayor parte, no conocen los proyectos que se están implementando en la región y no ven perspectivas de carrera, lo que confirma la implementación de muchos proyectos estratégicos de la región solamente. en papel. La falta de medidas para prevenir la emigración de los jóvenes tendrá una serie de consecuencias económicas y sociales negativas, una de las cuales es la reducción de la competitividad del territorio. La creación de condiciones favorables para los jóvenes de la región, una política pública activa para atraer a jóvenes profesionales calificados en Primorye es un requisito previo para el desarrollo del capital intelectual de la región y una garantía de su dinámico desarrollo socioeconómico.

Palabras clave: Migración; Preferencias de migración; Migración de estudiantes; Características regionales.

\section{Introduction}

In modern conditions of high territorial mobility of the population, migration is a powerful factor influencing both the development of regions and their stagnation, which strengthens its value in depopulation conditions of the population. The development of the regions of Russia is under the intense influence of the interaction of political, social, economic factors, the increased influence of demographic features on the quality of life indicators. The Far East is no exception. The problem of preservation of labor resources and emigration of the population from its territory remain relevant for this region. Today, the Far East is viewed by the Russian government as one of the key centers for the country's socio-economic development. A new model for the functioning of the region is based on exporting goods, works, services to the Asia-Pacific countries, creating a competitive investment climate, improving the efficiency of small and medium-sized businesses, creating competitive TORs, in other words, raising its economy and infrastructure, and creating new industries and jobs. However, a number of acute problems remain today. The most important of them are the departure of the economically active population outside the region. Thus, the Primorsky Region was left by 80,267 persons in 2016, 81,210 - in 2017, 82,567 - in 2018 (Official website of the Federal State Statistics Service). Moreover, the influx of migrants does not cover the outflow, the annual migration decline in the population varies between 4,500 and 5,500 people. The current trend in recent years indicates a high level of internal migration, including youth from the regions of the Far East.

In order to assess the threat of leakage of capable population, it is necessary to understand the intentions of youth migration, since they are the future of the region and the nation. We can complete the task by conducting a survey in their environment.

The purpose of this work is to study the causes of youth migration in one of the regions of the Far East - Primorsky Region. The study is aimed at obtaining ideas about migration attitudes and motivation of student migration behavior, information about the effectiveness of territory management through the feelings of young people.

\section{Methods}

Many domestic and foreign researchers, such as Molodikova and Duuvel, (2009); Heisler, (2000); Chiswick, (2000), Diner Hasia, (2000); Iontsev (1999); Zinchenko (2003); Dmitriev, (2006) studied migration of the population. Migration issues, migration policy issues, migration of certain groups of the population were considered in the works of such scholars (Rybakovsky, 2008; Rybakovsky, 2015; Vitkovskaya, 2000; Mukomel, 2005; Oreshkov, 2008; Mkrtchyan, 2013; Khudaveryan, 2012). Various aspects of youth migration in the Far Eastern territories were touched upon in the works of Baykov and Berezutsky (2008); Slobodianyuk, (2012); Shashlo, 
Petruk, Korostelev, (2018); Osipov and Krasova, (2015); Zubkov, (2016), Shkurkin and Lutsenko (2017); [ Baldina, Petruk and Lebedinskaya, (2017); Kim, Dremlyuga, and Smolyaninova (2018); Kashnitsky, (2013).

Nevertheless, despite the considerable elaboration of this topic, it does not lose its relevance at the present time. Particularly interesting is the study of the causes of migration of certain groups of the population from the regions, in particular, young people, since it is the one that acts as a catalyst for the effectiveness of control actions on the territory.

To study the migration of students and graduates of schools, a survey method was used a psychological verbal-communicative method in which information from the respondent was collected through a specially designed list of questions. Using this method, reliable primary data were obtained with minimal cost and high level of mass research. A feature of the chosen method is its anonymity (only respondents' answers were recorded without specifying personal data). The survey allowed to cover about 1,000 respondents aged 15 to 30 years old. We used selective, fulltime survey. In a relatively short time, an opinion on migration issues has been revealed.

\section{Main Findings of the Study}

The problem of attracting and preserving labor resources has always remained particularly relevant for the south of the Far East of Russia, and the role of migration in the dynamics of the population of Primorye was significant during all periods of its development. Migration processes cover almost all segments of the population, especially at working age. Student migration is one of the forms of a new type of migration, which most often occurs with an aim of receiving education outside the territory of its residence.

Migration attitudes of former schoolchildren allow studying the answers to a number of questions (for example, ascertaining the migration preferences of high school students for the purpose of education).

The first question was to study the factors influencing the choice of the university of future applicants. Thus, $52.1 \%$ consider that the most important is the presence of the desired areas of training, and $49 \%$ - the prestige of the educational institution. The third and fourth places are taken by the following factors: the opportunity to study for free $(43.2 \%)$ and practiceintegrated education (41.9\%), which makes it possible to find a job in the learning process. If we compare the relationship between the reasons for the choice of a university by high school students depending on their progress, then we observe the following pattern: The main factor in choosing the university by "A" students is the prestige of the educational institution (18\% of the selected answers); and the most important for "B" and "C" students when choosing a university is "the presence of the desired areas of training".

Priorities of high school students of Primorsky Region in choosing the university after graduation were as follows:

- in universities in Moscow or St. Petersburg - 34.7\%,

- outside the Primorsky Region (except Moscow and St. Petersburg) - 13.8\%,

- in universities outside Russia - 4.9\%,

- in universities of Primorsky Region - 46.6\%.

It should be noted that the priorities in choosing a university differ somewhat depending on the respondent's progress. Thus, schoolchildren who study "satisfactorily", choose the universities abroad and outside of Russia and Primorsky Region less often than "A" and "B" students. $22.6 \%$ of "A" students, $18 \%$ of "B" students, and only $11 \%$ of the respondents, who identified themselves as " $\mathrm{C}$ " students, would like to study after graduation in the universities in 
Moscow or St. Petersburg. Obvious becomes the fact that promising workers want to leave the region.

All respondents noted a whole range of reasons why they would like to leave the region. As the survey results show, the main reasons for the migration of graduates from the Primorsky Region are as follows:

- $\quad$ desire to get a more prestigious diploma (32.2\%);

- desire to see the world (30.3\%);

- conviction that it is easier to find work outside the Primorsky Region (26.0\%);

- $22.8 \%$ of respondents believe that the universities outside the Primorsky Region will provide more comfortable conditions for studying and living;

- the lack of prospects for the development of the region (19.2\%).

Analyzing the migratory mood among young people, a survey of university graduates was conducted, allowing us evaluating their opinions about the desire to change their place of residence after graduation. The answers of young people from Primorsky Region in general and Vladivostok in particular clearly show that young people do not see opportunities for selfrealization in Primorsky Region and prospects for its development. For example, $8.86 \%$ of undergraduate graduates want to build their professional careers and further life in Moscow and St. Petersburg. Another $7.5 \%$ of graduates want to leave the Primorsky Region (but not to Moscow and St. Petersburg). Almost 9\% of respondents are going to live abroad. Despite the fact that some graduates of universities in the Primorsky Region are going to build a professional career outside the city of Vladivostok, where the university they study is located, almost half of all undergraduate undergraduates are going to live and work in the city where they study. Such a "return" migration is largely forced and is associated primarily with the presence of housing or social connections in the hometown, which can be judged by the results of answers to the survey: "What does attract you to the city or country where you are going to live after graduation?" Migratory mood of graduate students (Table 1) significantly differs from the mood of graduates of undergraduate and graduate schools.

Table 1.

Migration mood of graduate students

\begin{tabular}{lc}
\hline Migration mood & $\begin{array}{c}\% \text { of } \\
\text { the number of students } \\
\text { surveyed }\end{array}$ \\
\hline Going to stay in the city where the university is located & $76.6 \%$ \\
Not yet decided & $10 \%$ \\
Going to relocate (potential migrants): & $10.0 \%$ \\
- to another city/town in Russia outside the region (Primorsky & \\
Region) & $3.3 \%$ \\
- abroad & $3.3 \%$ \\
- to Moscow or St. Petersburg & $0 \%$ \\
- to the city/town where they came from & \\
\hline
\end{tabular}

Thus, the "suitcase mood" of graduate students can be estimated at 13-18\%. Internal migrants prevail within the migration flow $-75 \%$.

For students, the main reasons for choosing a place to stay after graduation are: this is my hometown/country (37.8\%); my relatives and friends live there (they can help, support) (34.3\%); there is a possibility of career growth $(26.1 \%)$; there is a higher level of wages $(25.8 \%)$; I can find 
an interesting job there (25.6\%); more employment opportunities (25.1\%); there is where to live $(19.7 \%)$.

The problem of motivation of migration behavior is of undoubted interest. The main reasons why respondents after graduation would like to leave Primorsky Region and Russia are presented in Table 2.

Table 2.

The reasons that determine the reluctance to live in Primorsky Region and Russia

\begin{tabular}{lc}
\hline List of answers & $\mathbf{\%}$ \\
\hline Low salary & 31.13 \\
Weak employment prospects for university graduates without work experience & 45.3 \\
Weak employment prospects for university graduates in the specialty & 22.7 \\
Impossibility of career growth & 14.17 \\
Instability of the political and socio-economic situation & 20.73 \\
High unemployment & 8.5 \\
Other reasons & 7.3 \\
\hline
\end{tabular}

Two reasons lead in popularity among both bachelors and undergraduates: low wages and weak employment prospects. According to the respondents, the choice of place of residence outside the Primorsky Region was also influenced by the instability of the political and socioeconomic situation; the impossibility of career growth.

In assessing the development prospects of Primorsky Region, there is a difference in the responses of different groups of respondents. Potential emigrants (who would like to live after graduation abroad), compared with internal migrants, add such a reason as "instability of the political and socio-economic situation" (42.6\%). The respondents are rather pessimistic about the prospects for the development of Primorsky Region. 26\% of those, who want to stay in the Primorsky Region, believe that the region is dynamically developed. At the same time, $10.6 \%$ of those who want to go abroad adhere to this opinion. The majority of respondents believe that individual projects are being implemented, but in general, the economy is not developed (32\% of respondents) and the region is not dynamically developed (27.7\% of respondents). The same picture is observed for those who want to leave the Primorsky Region, but not the country. The answers of young people indicate that the majority of students believe that, in general, the economy does not develop in the region and the standard of living remains the same. Only $61.6 \%$ of respondents said that they were familiar with promising development projects of the Primorsky Region, in particular, with the project "Free Port of Vladivostok", 36.2\% heard about the project "Advanced Development Territory (TOR)". 2.2\% are informed about some other development projects of the Primorsky Region.

Thus, a negative attitude towards the socio-economic situation in Russia and the region is stimulated by the departure of graduates of undergraduate and graduate programs from the Primorsky Region after graduation. In addition, there is a connection between negative assessments of the socio-economic situation in Russia and the development prospects of the Primorsky Region with the respondents' intentions to leave the Primorsky Region and Russia.

\section{Conclusions}

Young people who have traveled abroad or outside the region, as a rule, do not return, and every year the territory is losing more and more young, active and educated citizens, so the problem of reproduction of the population and valuable labor resources is exacerbated. Emigration of young people outside the region also strengthens its consequences: a decrease in the region's 
competitiveness in the labor market, a decrease in the number of talented youth and, as a result, a decrease in the region's human capital, neglect and lack of attractiveness of cities that do not have young people, reduction in scientific potential that directly affects scientific and technical progress of the region.

Despite the fact that the government has been pursuing an active policy aimed at developing the Far Eastern territories and attracting the population there in recent years, its territory is losing more and more of the population as a result of migration outflow. One of the active migration groups is youth - the future of the region. The study results showed that potential young migrants want to go both abroad and to the central part of Russia. The main reasons for choosing a place to live outside the region are: instability of the political and socio-economic situation, poor employment prospects, lack of career prospects in the region.

Undoubtedly, migration has a tremendous impact on the socio-economic development of the region, especially if this is due to the outflow of young people. The lack of control over emigration leads to a number of negative consequences, in particular, to a decrease in the birth rate, an increase in social tension and an increase in structural imbalances. Creating favorable conditions for retaining young people in the region, an active state policy in attracting young qualified specialists in the Primorsky Region shall be a prerequisite for the development of intellectual capital in the region.

\section{References}

Baldina, Yu. V., Petruk, G. V., \& Lebedinskaya, Yu. S. (2017). Public and private sector entrepreneurship as a tool of dynamic functioning of tourism cluster at the territories of outstripping development (case study of Primorsky Region, Russian Federation). Economic and Social Changes: Facts, Trends, Forecast, 10(1), 200-217.

Baykov, N. M., \& Berezutsky, Yu. V. (2008). Far Eastern Youth as a Subject of Migration Attitudes. Power and Administration in the East of Russia. - Khabarovsk: DVAGS, 4(45), 110-117.

Chiswick, B. R. (2000). The Sociology of Immigration. Migration Theory: Talking across Disciplines, ed. by Caroline B. Brettell and James F. Hollifield. - New York: Routledge, pp. 77-96.

Diner Hasia, R. (2000). History and the Study of Immigration. Narratives of the Particuler. Migration Theory: Talking across Disciplines, ed. by Caroline B. Brettell and James F. Hollifield. - New York: Routledge, pp. 27- 42.

Dmitriev, A. (2006). Migration: Conflict Dimension. Routledge: Alfa-M, p. 516.

Heisler, B. S. (2000). The sociology of immigration. Migration theory: talking across disciplines. New York, 80-84.

Iontsev, V. A. (1999). International Migration of the Population: Theory and History of Study. M.: Publishing House of the Moscow State University.

Kashnitsky, I. (2013). Cohort Research on Russian Youth Intraregional Migration and Education. Beder Journal of Educational Science, 4(1), 22-30.

Khudaveryan, V. Ts. (2012). Youth Migration in the Modern World: Causes and Consequences. Knowledge. Understanding. Skill, 2, 142-148.

Kim, A. G., Dremlyuga, O. A., \& Smolyaninova, E. N. (2018). Social Problems of Migration Behavior of Young People in Modern Conditions. Azimuth of Scientific Research, 7(4(25)), 125-128.

Mkrtchyan, N. V. (2013). Youth Migration to Regional Centers of Russia at the end of the XX beginning of the XXI centuries. News of the Russian Academy of Sciences. Geographical Series, 6, 19-32.

Molodikova, I., \& Duuvel, F. (Ed.) (2009). Transit Migration and Transit Countries: Theory, Practice, and Regulatory Policy. M.: Universitetskaya Kniga, p. 392

Mukomel, V. I. (2005). Migration Policy of Russia: Post-Soviet Contexts. M.: Dipol-T, P. 203.

Official website of the Federal State Statistics Service [Electronic resource]. http://www.gks.ru 
Oreshkov, S. V. (2008). Illegal Migration as a Threat to Economic Security. Nauchnaya: Kniga, p. 168 .

Osipov, V. A., \& Krasova, E. V. (2015). Features of forming of a manpower in strategically important cities of the Far East of Russia (on the example of Vladivostok). Mediterranean Journal of Social Sciences, 6(5S3), 108-117

Rybakovsky, L. (2008). Migration of the Population. Three Stages of Migration Process. p. 113.

Rybakovsky, O. L. (2015). Permanent Migration of the Population of the Russian Regions. O.L. Rybakovsky, V.S. Sudoplatova. Population, 3, 4-14.

Shashlo, N. V., Petruk, G. V., \& Korostelev, A. A. (2018). Determinants of integration interaction among the subjects of the entrepreneurial innovation ecosystem of macro region. Amazonia Investiga, 7(13), 351-363.

Shkurkin, A. M., \& Lutsenko, E. L. (2017). Migration of Russian Youth in the Regional Dimension: Far East View. The Standard of Living of the Population of the Regions, 2(204), 78-82.

Slobodianyuk, M. G. (2012). The Role of Educational Potential in the Formation of the Migratory Mood of the Youth of the Far East of the Russian Federation. Power and Administration in the East of Russia, 4, 193-200.

Vitkovskaya, G. (2000). Migration and Security in Russia. Russia.

Zinchenko, N. (2003). Population Migration: Theory and Practice of International Legal Regulation. M.: Vneshtogizdat, p. 285

Zubkov, V. V. Life Plans and Migration Potential of Graduates of Far Eastern Universities: a Sociological Approach [Electronic resource] Pandia.ru: Encyclopedia of Knowledge. http://www.pandia.ru/text/78/324/2407 